\title{
Current Status and Recent Achievements of the Sterile Insect Technique Program Against Dengue Vector, Aedes aegypti, in Indonesia
}

\author{
B. Ernawan ${ }^{*}$, H.I. Sasmita, M. Sadar and I. Sugoro \\ Center for Isotopes and Radiation Application, National Nuclear Energy Agency \\ Jl. Lebak Bulus Raya No.49, Jakarta 12070, Indonesia
}

\section{ARTICLE INFO}

\section{Article history:}

Received 21 November 2018

Received in revised form 25 February 2019

Accepted 9 March 2019

\section{Keywords:}

Supply some 4-6 keywords

Sterile insect technique

Aedes aegypti

Indonesia

\begin{abstract}
A B S T R A C T
Given the facts that Indonesia has suitable environment condition to survival, reproduction and development of the principal mosquito vector for dengue virus, Aedes aegypti, the transmission of dengue virus does routinely occur every year. The sterile insect technique (SIT) as one of the techniques in area-wide integrated pest management (AW-IPM) has been developed to control Aedes aegypti population since 2004. The first 5 years of the program (2004-2009) was focused on mass rearing facility establishment. The lab-work study for the entomological data and field trials were performed in 2010-2014. In 2014-2019, the program was addressed to enhance the mass rearing facility to increase sterile male production and strengthening the networking throughout the involvement in the regional and interregional program coordinated by International Atomic Energy Agency (IAEA). The main future challenge of the SIT program against Aedes aegypti is developing the capacity building and strong commitment of all stakeholders i.e. the Ministry of Health, the universities, the research institutes and the public. In the future work plan, the pilot project design to proof the concept of the SIT is strongly recommended to obtain a firm, unbiased and strong results as the consideration for the decision maker to create the Aedes control program in Indonesia.
\end{abstract}

\section{INTRODUCTION}

Dengue hemorrhagic fever (DHF) is one of the main health problems in the world, particularly in tropical regions. In Indonesia, the epidemic of this disease was first recognized in Jakarta and Surabaya (Java Island) in 1968 [1]. Based on annual reports provided by The Ministry of Health since 1968, the incidence rate caused by dengue virus (DENV), has been increasing annually. The latest report (2016) showed nearly $85 \%$ of the districts/cities in Indonesia have been infected by DENV. Many studies reported that four distinct dengue virus serotypes (DENV-1, -2, -3 and -4) identified circulating in Indonesia. This virus mainly transmitted by Aedes aegypti mosquito [2-5].

* Corresponding author

E-mail address: beni_e@batan.go.id

DOI: https://doi.org/10.17146/aij.2019.908
Aedes aegypti is the most popular species because of their role as the vector of the deadly disease, especially dengue. This species can be found in rural as well as the urban area. Larvae are able to develop in stagnant water around the domestic household that can increase their probability for transmitting the disease to human [6].

The current vector control method initiated by the Ministry of Health emphasized on mosquito (Aedes aegypti) source reduction which implemented periodically is coordinated by the local Public Health Office (Dinas Kesehatan). Furthermore, the massive utilization of insecticides is still become the major strategy to combat mosquito, while biological control strategies, such as Bacillus thuringiensis bacteria, larvivorous fish and arthropod are not excessively implemented. Hence, the environment-friendly and an effective method necessary to be developed on DHF vector population control program. 
The sterile insect technique (SIT) is an increasingly important component of area-wide integrated pest management (AW-IPM) program with great application potential for use against insect pest. After the most successful of the SIT application on the screwworm eradication campaign in the United States until Central America [7], it has been elaborated to control another key insect, the mosquito. In Indonesia, this technique has been developed since 2004 led by Center for Isotopes and Radiation Application - National Nuclear Energy Agency of Indonesia (CIRA-BATAN), to control Aedes aegypti population. This short review is intended to provide a summary of the SIT program against Aedes aegypti in Indonesia since 2004 until the recent year. The information relies on the achievements, the future work plan and challenge of the SIT program.

\section{EXPERIMENTAL METHODS}

The experimental methods in the recent study were conducted using literature study approach. The literature sources with relevant issue and topic to the recent study were collected and reviewed. Then, the discussion was sequenced with the following segments.

\section{The SIT concept}

This segment discussed the short historical story of the SIT and also reviewed the SIT fundamental concept.

\section{The SIT program in Indonesia}

The SIT program against Aedes aegypti in Indonesia is discussed in this segment including the infrastructure (such as mass rearing facility and gamma irradiator) and also the field trials of the SIT.

\section{The future challenges}

The future work and challenges of the SIT program in Indonesia are presented in term of the geographic situation, capacity building, mass rearing enhancement, cost-benefit analysis and designing the pilot project.

\section{RESULTS AND DISCUSSION}

\section{The SIT concept}

The SIT represents one of the biological and genetic control methods which successfully applied to insect pest eradication and suppression in the large area. This technique was independently conceived by E. F. Knipling (United States Department of Agriculture), A. S. Serebrovskii (Moscow State University) and F. L. Vanderplank (Tsetse field research Station, Tanzania) in the 1940s [7,8]. Basically, the SIT is releasing a large amount of sterile male insect into the field. The mating between sterile male and wild female is expected to produce unviable eggs, thus resulted in the targeted species population $[9,10]$. In practice, this technique involves several works, i.e. mass production of insect; sterilization of male insect using ionization energy (gamma rays, X-rays, etc.); packaging, handling, transport and release sterile male; monitoring and evaluation, and social engagement $[9,11-15]$.

\section{SIT program towards the reduction of Aedes aegypti population}

The SIT program against Aedes aegypti in Indonesia was developed in 2004 led by CIRABATAN. In 2004-2009 period, the program was focused on the infrastructure establishment particularly mass rearing facility. The insectarium $\left( \pm 50 \mathrm{~m}^{2}\right)$ is located in entomology laboratory building of CIRA-BATAN, Jakarta. Initially, this insectarium is facilitated with limited equipment such as mosquito cage $(60 \times 60 \times 100 \mathrm{~cm})$, larval tray $(36 \times 26 \times 7 \mathrm{~cm})$ and the sieve for sorting the pupae. The mosquito strain was collected from the field and has been reared in the insectarium for generations. In this period, the facility was only able to produce 20,000 sterile males per week.

The other important infrastructure of SIT is gamma irradiator. To support the SIT program, CIRA-BATAN has several types of gamma irradiator which can be used to sterilize Aedes aegypti male. Those gamma irradiators are gamma cell 220, gamma chamber and panoramic (centered batch) irradiator. All of them use Cobalt-60 (Co-60) as the source.

In the following period (2010-2014), labwork studies and field trials were conducted. The lab-work study aimed to find the gamma irradiation-dose response of the Aedes aegypti. In this study, Aedes aegypti males at the pupal or adult stage were irradiated with gamma rays using gamma cell irradiator 220 in varies doses then evaluated their sterility and mating competitiveness (Table 1).

Based on Table 1, the sterility has a tendency to increase with the increasing gamma irradiation dose. While in the mating competitiveness, the value showed the contrary results. The maximum sterility was obtained at 70,80 and 100 Gy of 
gamma irradiation dose with the sterility were $100.00 \%$; $99.90 \%$ and $100.00 \%$ respectively. However, mating competitiveness at $100 \mathrm{~Gy}$ was the lowest compared to other doses. Therefore, the result can be concluded that the optimal gamma irradiation dose was around 70-80 Gy at the dose rate of $962.334 \mathrm{~Gy} / \mathrm{h}[16-18]$.

Table 1. The gamma-irradiation dose effects on the sterility and mating competitiveness of Aedes aegypti male [16,18].

\begin{tabular}{ccc}
\hline Dose (Gy) & Sterility $(\%)$ & Mating competitiveness \\
\hline 20 & 72.54 & 0.97 \\
40 & 83.32 & 0.4 \\
50 & 67.15 & 0.51 \\
55 & 69.25 & 0.47 \\
60 & 71.92 & 0.46 \\
65 & 98.53 & 0.45 \\
70 & 100.00 & 0.31 \\
80 & 99.90 & 0.32 \\
100 & 100.00 & 0.13 \\
\hline
\end{tabular}

A series of field trials in several areas in Indonesia was performed to prove the principal concept of SIT. The field trials were shown in Table 2.

All of the SIT implementation into the field (Table 2) were using 9:1 ratio of sterile male compared to wild female according to Knipling model and only five (5) times releasing of the sterile male [10]. The limitation of the previous field trials was the absence of the population dynamics of the Aedes aegypti in the studied area throughout the year before releasing the sterile male of mosquito. The population dynamic is one of the baseline data that is crucial to determine the time, quantity, and impact of releasing sterilized males. The other limitation was the high mortality of the sterile Aedes aegypti males during transportation. Even most of these field trials reported that the Aedes aegypti population has been reduced, the field trials method needs to be improved including packaging and transportation technique, population dynamic data throughout the year. The technique needs to be enhanced with the requirements for declaring pest (Aedes aegypti) free status [23].

Table 2. Field trials of the releasing sterile Aedes aegypti male.

\begin{tabular}{|c|c|c|c|c|c|}
\hline Year & Location & Transportation & Objective & Outcome & Ref. \\
\hline 2010 & $\begin{array}{l}\text { Pasar Jumat } \\
\text { Nuclear Area, } \\
\text { Jakarta }\end{array}$ & $\begin{array}{l}\text { No } \\
\text { transportation } \\
\text { needed }\end{array}$ & Population reduction & $\begin{array}{l}\text { Population reduced after several } \\
\text { times releasing of the sterile male }\end{array}$ & [19] \\
\hline 2011 & $\begin{array}{l}\text { Two villages ( } 99 \\
\text { households) in } \\
\text { Banjarnegara City, } \\
\text { Central Java }\end{array}$ & $\begin{array}{l}\text { By land, } \\
\text { transported at } \\
\text { the adult stage }\end{array}$ & Population reduction & $\begin{array}{l}\text { Five (5) times releasing (periodically } \\
\text { every week) of sterile male, reduce } \\
\text { egg-hatch fertility }\end{array}$ & [19] \\
\hline 2011 & $\begin{array}{l}\text { Muntok, Bangka } \\
\text { Belitung }\end{array}$ & $\begin{array}{l}\text { By air } \\
\text { (commercial } \\
\text { flight), } \\
\text { transported at } \\
\text { the adult stage }\end{array}$ & Population reduction & $\begin{array}{l}\text { Several times releasing, increased } \\
\text { egg-hatch sterility }\end{array}$ & Unpublished \\
\hline 2012 & $\begin{array}{l}\text { One village (100 } \\
\text { households) in } \\
\text { Salatiga, Central } \\
\text { Java }\end{array}$ & $\begin{array}{l}\text { By land, } \\
\text { transported at } \\
\text { the adult stage }\end{array}$ & $\begin{array}{l}\text { Population reduction } \\
\text { in urban area }\end{array}$ & $\begin{array}{l}\text { Five (5) times releasing (periodically } \\
\text { every week) of sterile male, } \\
\text { increased egg-hatch sterility. } \\
\text { Population was reduced around } 15 \%\end{array}$ & [20] \\
\hline 2012 & $\begin{array}{l}\text { One village (100 } \\
\text { households) in } \\
\text { Salatiga, Central } \\
\text { Java }\end{array}$ & $\begin{array}{l}\text { By land, } \\
\text { transported at } \\
\text { the adult stage }\end{array}$ & $\begin{array}{l}\text { Population reduction } \\
\text { in sub urban area }\end{array}$ & $\begin{array}{l}\text { Five (5) times releasing (periodically } \\
\text { every week) of sterile male, } \\
\text { increased egg-hatch sterility. } \\
\text { Population was reduced around } 80 \%\end{array}$ & [21] \\
\hline 2014 & $\begin{array}{l}\text { Semarang, Central } \\
\text { Java }\end{array}$ & $\begin{array}{l}\text { By land, } \\
\text { transported at } \\
\text { the adult stage }\end{array}$ & Population reduction & $\begin{array}{l}\text { No population reduction after five } \\
\text { (5) times releasing (periodically } \\
\text { every week) of the sterile male }\end{array}$ & [22] \\
\hline 2016 & $\begin{array}{l}\text { Tebing Tinggi, } \\
\text { North Sumatera }\end{array}$ & $\begin{array}{l}\text { By air (cargo), } \\
\text { transported at } \\
\text { the pupa stage }\end{array}$ & $\begin{array}{l}\text { The transportation } \\
\text { effects to the quality } \\
\text { of sterile male of } \\
\text { mosquito }\end{array}$ & $\begin{array}{l}\text { More than } 70 \% \text { mortality. Probably } \\
\text { due to the storage condition in cargo } \\
\text { service which not suitable to the } \\
\text { sterile male of mosquito. }\end{array}$ & Unpublished \\
\hline 2016 & $\begin{array}{l}\text { Banjarnegara, } \\
\text { Central Java }\end{array}$ & $\begin{array}{l}\text { By land, } \\
\text { transported both } \\
\text { at the pupa and } \\
\text { adult stage }\end{array}$ & $\begin{array}{l}\text { The transportation } \\
\text { effects to the quality } \\
\text { of sterile male of } \\
\text { mosquito }\end{array}$ & $\begin{array}{l}\text { Around } 40 \% \text { mortality, reduced } \\
\text { longevity and competitiveness }\end{array}$ & Unpublished \\
\hline
\end{tabular}


In the next five years (2015-2019 period), the program was addressed to enhance mass rearing facility and strengthening the networking on the SIT development throughout the national, regional and interregional program coordinated by International Atomic Energy Agency (IAEA). In the regional program, we involved in IAEA-RAS/5/066 2017 (accomplish) and IAEA-RAS/5/082. While in the interregional program, we involved in IAEAINT5155. All programs are focused on the development of the sterile insect and related technique against vector insects. The other involvement in IAEA program is the coordinated research project (CRP) D44002 which focused on the mosquito handling, packaging, transport, release and male trapping methods. In this period, a study of the effects of transportation on sterile male Aedes aegypti was also conducted in 2016 (see Table 2).

\section{Future challenges}

\section{Geographic condition}

Indonesia is an archipelago, situated between the Indian Ocean and the Pacific Ocean and between Asia main Continental and Australia Continental. The climate classified as tropical with high humidity, precipitation and warm temperature. This condition is suitable for Aedes aegypti survival, reproduction and development as well as the dengue virus (DENV). Technically, the SIT program in Indonesia faced the fact that the gamma irradiator does only exist in Jakarta (Java Island), while the DENV is spreading in almost entire Indonesia territory. With respect of this situation, the main challenge can be addressed to the developing the package and transportation methods and maintaining the quality of sterile Aedes aegypti male from gamma irradiator facility (Jakarta) to some other areas in Indonesia.

\section{Capacity building of the program}

The key success of the SIT application is the development of the capacity building of all stakeholders to reach public and regulatory acceptability. The stakeholders can be described as follows: CIRA-BATAN and University as the technical research institutes; Ministry of Health as the policy maker; private company, non-government organization and public as the social support and user. Oliva et al. in 2014 described the interaction between technical research and social sciences in the implementation of the SIT program [24]. The technical research in term of SIT needs to be advanced in all aspects involves mass rearing, sex separation, sterilization, packaging, transportation and release methods. The strong scientific data could regain the attention of the central government, noticing that the SIT as the potential and promised technique against mosquito [25]. While social science plays a role to transfer the knowledge of technical research to the public. The strong commitment and collaboration between technical research and social science will increase the public attention and participation on the SIT project [24].

\section{Scaling-up the male production}

It is clear that the success of SIT depends on the high possibility of mating between sterile male and wild female. So, the next challenge is producing the competitive sterile male in large number from the mass rearing facility. Recently, we can only produce 200,000 sterile males per week which are the sufficient number for the SIT application on the operational scale. In order to increase the high quality of sterile Aedes aegypti male production, mass rearing aspect should be improved. This work relies on the strain management $[11,13]$, the facility enhancement $[26,27]$, the larval diet optimization [28-30], the sex separation technique [31] and the quality control $[32,33]$.

\section{Cost-benefit analysis}

The economic issue always becomes the main concern of the discussion in the vector control program. Hence, the benefit-cost analysis (BCA) of the SIT program should be conducted to see the effectiveness of the cost-benefit ratio compared to the conventional method. The BCA is essentially to support the scientific data in order to get public and regulatory acceptance [34]. Mumford in 2005 explained that the BCA includes several phases i.e.: preparatory phase, control/treatment phase and post-treatment or maintenance phase [35]. In the preparatory phase, the cost involves research, feasibility study, baseline-data collection, construction of the infrastructure for mass rearing and irradiator facility, public relation, etc. This phase also requires the highest cost investment, particularly on the infrastructure construction. In the second phase, the control/treatment phase, the cost depends on the strategic approaches which are eradication, suppression, containment and replacement. The main activity of this phase is releasing the sterile male into the area. Then in the last phase, the post-treatment or maintenance phase, the cost includes surveillance and emergency plan.

Since it is not easy to measure the direct benefit from the human health, we can analyze the 
indirect benefit of the SIT program against the dengue vector. The costs reduction compared to the conventional method, reduce the use of insecticide, reduce the environmental impact, reduce the dengue treatment costs and increase the productivity.

Alphey et al. [36] proposed the model framework to estimate the cost-benefit of dengue vector control using the release of insect carrying a dominant lethal (RIDL) technology that can be adopted in the SIT. The cost consisted the construction and operation of the SIT. While the indirect benefit calculated from the cases averted and cost per case averted. The model was designed in two populations ( 2 million and 10 thousand population) and each model estimated the cost and benefit in two scenario programs ( 5 and 10 years of the operational program). The model highlighted in Table 3.

Table 3. Cost-benefit simulation [36].

\begin{tabular}{|c|c|c|}
\hline & \multicolumn{2}{|c|}{ Population } \\
\hline & $2,000,000$ & 10,000 \\
\hline \multicolumn{3}{|l|}{ Five-year program } \\
\hline $\begin{array}{l}\text { Total released in } 5 \text { years } \\
\text { (millions) }\end{array}$ & 5254.3 & 26.3 \\
\hline $\begin{array}{l}\text { Total (construction+operational) } \\
\text { costs: mean (US\$ millions) }\end{array}$ & 6.246 & 0.034 \\
\hline Cases averted in 5 years & 243,532 & 1,179 \\
\hline Cost per case averted (mean) & US $\$ 25.65$ & US\$29.11 \\
\hline $\begin{array}{l}\text { Incremental cost-effectiveness } \\
\text { ratio }\end{array}$ & US\$1498 & US\$939 \\
\hline \multicolumn{3}{|l|}{ Ten-year program } \\
\hline $\begin{array}{l}\text { Total released in } 5 \text { years } \\
\text { (millions) }\end{array}$ & 10468.6 & 52.3 \\
\hline $\begin{array}{l}\text { Total (construction+operational) } \\
\text { costs: mean (US\$ millions) }\end{array}$ & 10.485 & 0.056 \\
\hline Cases averted in 5 years & 491,664 & 2,403 \\
\hline Cost per case averted (mean) & US $\$ 21.33$ & US\$23.10 \\
\hline $\begin{array}{l}\text { Incremental cost-effectiveness } \\
\text { ratio }\end{array}$ & US\$2524 & US\$1545 \\
\hline
\end{tabular}

\section{Designing the pilot project}

Future work plan of the project is designing a pilot project prior to prove the SIT concept with the step-wise program comprehensively. The project site will be planned in Pasar Jumat-Lebak Bulus, Jakarta (Fig. 1). The brown, pink and blue color represent the treatment area ( $25 \mathrm{ha})$, the control area (10 ha) and the nuclear area of BATAN (20 ha), respectively, where mass rearing and gamma irradiator facilities exist. The treatment area situated between highway road in the right site and the river at the left side. In both treatment and control areas BG-Sentinel traps (Biogents, Germany) and ovitraps will be deployed to analyze the population dynamics of Aedes aegypti.

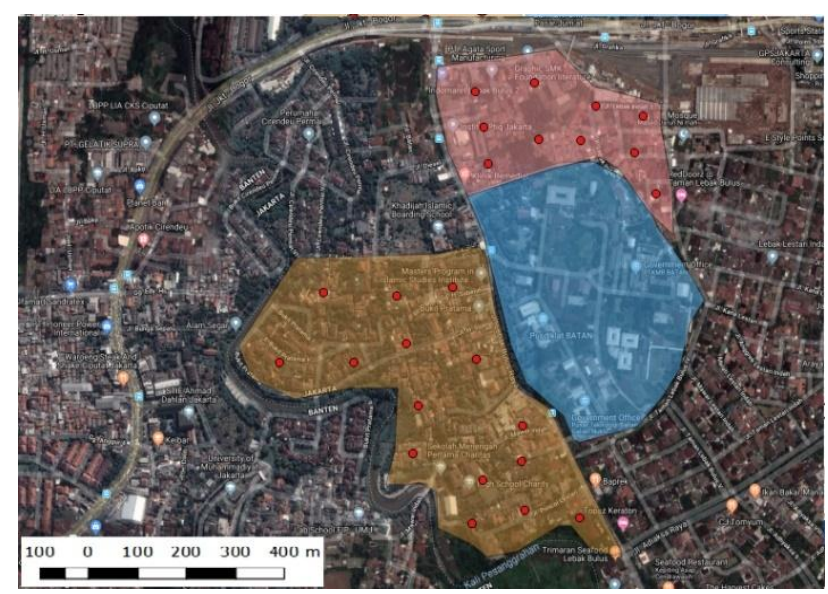

Fig. 1. Pilot project site in Pasar Jumat-Lebak Bulus, Jakarta.

The time schedule of the pilot project will be sequenced as the following: finding the pilot project site, collecting the baseline data, increasing the mass rearing production and all laboratory activity will be done in the first two years. While building capacity and social engagement of all stakeholders will be conducted parallel with laboratory and field activities in the first two years. Then in the third year, it will be expected to start releasing sterile Aedes aegypti male into the pilot project site throughout the year. The releasing process of the sterile male of mosquito will be conducted periodically every week until the population in the studied area suppressed. The number of sterile males that will be released are using the overflooding concept, which is releasing large number of sterile males compared to the wild-type population that calculated according to the population dynamics analysis. In the fourth or fifth year, it will be expected to obtain a strong and comprehensive result with firm and unbiased data as the consideration to the policy maker to create the Aedes control program in Indonesia.

\section{CONCLUSION}

The SIT program against dengue vector, Aedes aegypti, in Indonesia has been elaborated since 2004 led by National Nuclear Energy Agency of Indonesia. Since the program started, some achievements have been reached such as the mass rearing and gamma irradiator facilities establishment, the lab-work study regarding the optimal gamma-irradiation dose response and field trials of the SIT application. Some cooperation in national, regional and international level also have been conducted to strengthening the networking in the SIT development. However, the future challenges in term of the geographic condition, capacity building and mass rearing 
enhancement need to be identified and solved to develop the SIT program in the future. In the future work plan, the designing pilot project in order to prove the concept of the SIT is strongly recommended to obtain a firm, unbiased and strong results as the consideration for the decision maker to create the Aedes control program in Indonesia.

\section{ACKNOWLEDGEMENT}

Authors are grateful to the Center for Isotopes and Radiation Application-National Nuclear Energy Agency (CIRA-BATAN) for the financial support of the SIT development program. We also acknowledge the International Atomic Energy Agency (IAEA) through RAS5066, RAS5082, INT5155 and the Coordinated Research Project (CRP) D44002 (Contract No. 19098) programs for the supervision and technical support.

\section{REFERENCES}

1. M.A. Nathin, S.R. Harun and Sumarmo, Southeast Asian J. Trop. Med. Public Health 19 (1988) 475.

2. K.R. Porter, C.G. Beckett, H. Kosasih et al., Am. J. Trop. Med. Hyg. 72 (2005) 60.

3. A. Yamanaka, K.C. Mulyatno, H. Susilowati et al., PLoS One 6 (2011) 1.

4. A. Suwandono, H. Kosasih, Nurhayati et al., Trans. R. Soc. Trop. Med. Hyg. 100 (2006) 855.

5. S. Fahri, B. Yohan, H. Trimarsanto et al., PLoS Negl. Trop. Dis. 7 (2013) 1.

6. C.C. Jansen and N.W. Beebe, Microbes Infect. 12 (2010) 272.

7. W. Klassen and C.F. Curtis, History of The Sterile Insect Technique, in: Sterile Insect Technique, V.A. Dyck, J. Hendrichs, A.S. Robinson (Ed.), Springer, The Netherlands (2005) 3.

8. E.F. Knipling, Science 130 (1959) 902.

9. W. Klassen, Area-Wide Integrated Pest Management and The Sterile Insect Technique, in: Sterile Insect Technique, V.A. Dyck, J. Hendrichs, A.S. Robinson (Ed.), Springer, The Netherlands (2005) 39.

10. E.F. Knipling, J. Econ. Entomol. 48 (1955) 459.

11. A.G. Parker, Mass-Rearing for Sterile Insect Release, in: Sterile Insect Technique, V.A.
Dyck, J. Hendrichs, A.S. Robinson (Ed.), Springer, The Netherlands (2005) 209.

12. A. Bakri, K. Mehta and D.R. Lance, Sterilizing Insects with Ionizing Radiation, in: Sterile Insect Technique, V.A. Dyck, J. Hendrichs, A.S. Robinson (Ed.), Springer, The Netherlands (2005) 233.

13. F. Balestrino, A. Puggioli, J.R.L. Gilles et al., PLoS One 9 (2014) 1.

14. R.V. Dowell, J. Worley and P.J. Gomes, Sterile Insect Supply, Emergence, and Release, in: Sterile Insect Technique, V.A. Dyck, J. Hendrichs, A.S. Robinson (Ed.), Springer, The Netherlands (2005) 297.

15. B. Ernawan and H.I. Sasmita, A Scientific J. for the Application of Isotopes and Radiation 13 (2017) 11. (in Indonesian) DOI: http://dx.doi.org/10.17146/jair.2017.13.1.3920

16. S. Nurhayati, B. Santoso, A. Rahayu et al., The Effects of Gamma Rays on The Mating Competitiveness of Aedes aegypti Mosquito as Dengue Hemorrhagic Fever (DHF), Proceedings of National Conference of Health and Environment Safety V (2009) 78. (in Indonesian)

17. B. Ernawan, H.I. Sasmita and A.A. Parikesit, The J. Anim. Plant Sci. 28 (2018) 973.

18. H.I. Sasmita and B. Ernawan, A Scientific J. for the Application of Isotopes and Radiation 10 (2014) 149. (in Indonesian) DOI: http://dx.doi.org/10.17146/jair.2014.10.2.2722

19. S. Nurhayati, B. Yunianto, T. Ramadhani et al., Indonesian J. Nuclear Sci. Tech. 14 (2013) 1. (in Indonesian) DOI: http://dx.doi.org/10.17146/jstni.2013.14.1.679

20. R. Setiyaningsih, M. Agustini, D.T. Boewono et al., Bulletin of Health Research 42 (2014) 15. (in Indonesian) http://ejournal.litbang.depkes.go.id/index.php/ BPK/article/view/3473

21. R. Setiyaningsih, M. Agustini, B. Heriyanto et al., Media of Health Research and Development 24 (2014) 1. (in Indonesian) http://ejournal.litbang.depkes.go.id/index.php/ MPK/article/view/3481

22. D. Puspitasari, Aedes Aegypti Mosquito Growth Survey with the use of Sterile Isect Technique (SIT) in Ngaliyan, Semarang, Undergraduate, Diponegoro University (2014). (in Indonesian) http://eprints.undip.ac.id/44770/ 
23. H.J. Barclay, J.W. Hargrove, A. Clift et al., Procedures for Declaring Pest Free Status, in: Sterile Insect Technique, V.A. Dyck, J. Hendrichs, A.S. Robinson (Ed.), Springer, The Netherlands (2005) 363.

24. C.F. Oliva, M.J.B. Vreysen, S. Dupe et al., Acta Trop. 132 (2014) 130.

25. M.Q. Benedict and A.S. Robinson, Trends Parasitol. 19 (2003) 349.

26. H. Maiga, N.S. Bimbile-Somda, H. Yamada et al., Entomologia Experimentalis et Applicata 164 (2017) 269.

27. M. Dogan, F. Gunay, A. Puggioli et al., Acta Trop. 159 (2016) 62.

28. A. Puggioli, F. Balestrino, D. Damiens et al., J. Med. Entomol. 50 (2013) 819.

29. R. Bellini, A. Puggioli, F. Balestrino et al., Acta Trop. 132 (2014) S116

30. J. Bouyer and T. Lefrancois, Trends Parasitol. 30 (2014) 271.
31. R. Bellini, A. Puggioli, F. Balestrino et al., Parasites and Vectors 11 (2018) 650.

32. F. Balestrino, A. Puggioli, M. Carrieri et al., PLoS Negl. Trop. Dis. 11 (2017) e0005881.

33. N.J. Culbert, F. Balestrino, A. Dor et al., Scientific Reports 8 (2018) 16179.

34. M.J.B. Vreysen, A.S. Robinson, J. Hendrichs et al., Area-Wide Integrated Pest Management (AW-IPM): Principles, Practice and Prospects, in: Area-Wide Control of Insect Pests, M.J.B. Vreysen, A.S. Robinson, J. Hendrichs (Ed.), Springer, The Netherlands (2007) 3.

35. J.D. Mumford, Application of Benefit/Cost Analysis to Insect Pest Control using the Sterile Insect Technique, in: Sterile Insect Technique, V.A. Dyck, J. Hendrichs, A.S. Robinson (Ed.), Springer, The Netherlands (2005) 481.

36. N. Alphey, L. Alphey and M.B. Bonsall, PLoS One 6 (2011) e25384. 